\title{
ANALISIS KETERAMPILAN GURU DALAM PENGELOLAAN KELAS PADA PEMBELAJARAN TEMATIK KELAS V DI SDN SUDIMARA 11 CILEDUG
}

\author{
Iin Wulandari ${ }^{1}$, Septy Nurfadhillah ${ }^{2}$ \\ ${ }^{1,2}$ Universitas Muhammadiyah Tangerang, Indonesia \\ Iinwulandari0710@gmail.com, nurfadhillahsepty@gmail.com
}

\begin{abstract}
Abstrak
Pembelajaran adalah proses interaksi peserta didik dengan pendidik dan sumber belajar pada suatu lingkungan belajar. Pembelajaran akan menjadi hidup tergantung bagaimana guru mengelola kelas dengan baik. Seperti halnya guru kelas V di SDN Sudimara 11 Ciledug mengelola kelas dengan baik pada pembelajaran tematik. Pengelolaan kelas sangat dibutuhkan guna mengoptimalkan pembelajaran. Oleh karenanya guru harus nemiliki keterampilan mengelola kelas diantaranya keterampilan guru dalam menciptakan kondisi belajar yang kondusif dan keterampilan guru dalam mengendalikan pembelajaran agar kembali kondusif. Penelitian ini bertujuan untuk mengetahui lebih lanjut tentang keterampilan guru dalam mengelola kelas pada pembelajaran tematik. Jenis penelitian ini merupakan penelitian lapangan ( field research) dan penelitian ini digolongkan kedalam studi kasus deskriptif kualitatif. Untuk keperluan pengumpulan data penelitian ini menggunakan metode observasi, dokumentasi dan wawancara. Sedangkan dalam menganalisis data peneliti mengguanakan pola induktif yaitu reduksi data, penyajian data, dan penarikan kesimpulan. Hasil penelitian ini diketahui bahwa keterampilan guru dalam pengelolaan kelas pada pembelajaran tematik kelas V di SDN Sudimara 11 dengan cara sebagai berikut: (1) Mengedepankan tiga aspek. Pertama, penguatan pendidikan karakter (PPK) pada kegiatan belajar mengajar seperti dalam diskusi jadi siswa disuruh untuk maju membacakan hasil diskusi. Diskusi tersebut dapat membantu membentuk karakter siswa agar lebih percaya diri, disiplin, dan aktif. Kedua, literasi. Pada setiap awal pertemuan siswa disuruh membaca materi atau cerita yang berkaitan dengan tema. Ketiga, keterampilan abad 21 atau disebut juga dengan 4C (Creative, Critical thinking, Communicative, dan Collaborative) yakni guru terkadang mengajak siswanya untuk belajar diluar kelas agar siswa tidak mudah bosan. (2) Menggunakan metode diskusi. Metode diskusi sering kali digunakan karena untuk melatih kepercayaan diri siswa, melatih siswa untuk berani mengungkapkan pendapatnya, melatih siswa untuk berani berbicara didepan kelas, melatih siswa untuk bekerja sama dan lain-lain.
\end{abstract}

Kata Kunci : Keterampilan Guru, Pengelolaan, Kelas, Pembelajaran, Tematik

\begin{abstract}
This research Is to aim at to know more about teacher skill in management class at thematic learning. This research is field research and be classified into qualitative descriptive case studies. For data collection, this research use observe method, documentation and interview. Mean While to data analysis, it use inductive method like reductive data, data presentation, and make conclusion. From this research can be know that teacher skill at management class at thematic learning at class 5 SDN sudimara 11 ciledug method is use 3 aspecs. First, build learning character at learning process like as discussion, so student read discussion result on front of class. Discussion can help student character to more confident, discipline, and active. Number two is literasion. At the first meet, student read the materi or story related to theme. Three, skill at 21 century or called with 4 C (Creative, Critical thinking, Communicative, dan Collaborative) is teacher sometimes ask their student to learn at outside of class so that student not get bored. (2) use discussion mehode. Discussion method usually used for student confident practice. Train student to be brave to speak their opnion, train student to be brave speak at front of class, train student to cooperate with the others
\end{abstract}

Keywords : Teacher Skills, Management, Classroom, Learning, Thematic 


\section{PENDAHULUAN}

Pendidik adalah pembimbing dan pengarah yang mengemudikan perahu tetapi tenaga untuk menggerakkan perahu tersebut haruslah berasal dari mereka atau peserta didik yang belajar. Jadi, para peserta didik harus didorong dan dirangsang untuk belajar bagi diri mereka sendiri dan tugas pendidik yang sebenarnya adalah menjamin bahwa peserta didik menerima tanggung jawabnya sendiri untuk belajar dengan mengembangkan sikap dan rasa antusiasme untuk keperluan ini. Tugas utama guru adalah menciptakan suasana didalam kelas agar terjadi interaksi belajar mengajar yang dapat memotivasi peserta didik untuk belajar dengan baik dan sungguh-sungguh. Untuk itu, pendidik seyogyanya memiliki kemampuan untuk melakukan interaksi belajar mengajar yang baik. Salah satu kemampuan yang sangat penting adalah kemampuan mengatur kelas/mengelola kelas. Sedangkan apabila seseorang yang cukup kompeten ditanya apa tugas pokok seorang pendidik, maka secara spontan ia akan menjawab mendidik dan mengajar. Mendidik bukanlah tugas sederhana, pendidik yang sesungguhnya harus mampu membawa peserta didik beranjak dari kegelapan menuju suatu pencerahan yang terang benderang. Pendidik yang profesional adalah guru yang tahu mendalam tentang apa yang diajarkan, mampu mengajarkannya secara efektif, efisien, dan berkepribadian mantap. Pendidik yang bermoral tinggi dan beriman tingkah lakunya digerakkan oleh nilai-nilai luhur. Jadi tugas pokok pendidik adalah mengajar peserta didik.

Pengelolaan kelas adalah keterampilan guru untuk menciptakan dan memelihara kondisi belajar yang optimal dan mengembalikannya bila terjadi gangguan dalam proses belajar mengajar. Pengelolaan kelas adalah salah satu tugas pendidik yang tidak pernah ditinggalkan. Tugas pendidik didalam kelas sebagian besar adalah membelajarkan siswa dengan menyediakan kondisi belajar yang optimal. Kondisi belajar yang optimal dapat dicapai jika guru mampu mengatur peserta didik dan sarana pengajaran serta mengendalikannya dalam suasana yang menyenangkan untuk mencapai tujuan pelajaran. Pengaturan berkaitan dengan penyampaian pesan pengajaran (instruksional), atau dapat pula berkaitan dengan penyediaan kondisi belajar (pengelolaan kelas). Bila pengaturan kondisi dapat dikerjakan secara optimal, maka proses belajar berlangsung secara optimal pula. Tetapi bila tidak dapat disediakan secara optimal, tentu saja akan menimbulkan gangguan terhadap belajar mengajar. Gangguan dapat bersifat sementara sehingga perlu dikembangkan lagi kedalam iklim belajar yang serasi (kemampuan mendisiplinkan), akan tetapi gangguan dapat 
pula bersifat cukup serius dan terus menerus sehingga diperlukan kemampuan meremidi. Disiplin itu sendiri sebenarnya merupakan akibat dari pengelolaan kelas yang efektif. Yang jelas pengelolaan kelas yang efektif merupakan prasyarat mutlak bagi terjadinya proses belajar mengajar yang efektif. Hal lain yang juga ikut menentukkan keberhasilan pendidik dalam mengelola kelas adalah kemampuan pendidik dalam mencegah timbulnya tingkah laku peserta didik yang mengganggu jalannya kegiatan belajar mengajar serta kondisi fisik tempat belajar mengajar dan kemampuan pendidik dalam mengelolanya.

Usaha pendidik dalam menciptakan kondisi yang diharapkan akan efektif apabila: pertama, diketahui secara tepat faktor-faktor yang dapat menunjang terciptanya kondisi yang menguntungkan dalam proses belajar mengajar. Kedua, dikenal dengan masalah-masalah yang diperkirakan dan biasanya timbul dan dapat merusak iklim belajar mengajar. Ketiga, dikuasainya berbagai pendekatan dalam pengelolaan kelas dan diketahui pula kapan dan untuk masalah mana suatu pendekatan digunakan. Suatu masalah yang timbul mungkin dapat berhasil diatasi dengan cara tertentu dan untuk seseorang atau sekelompok peserta didik tertentu. Akan tetapi cara tersebut tidak dapat dipergunakan untuk mengatasi masalah yang sama, pada waktu yang berbeda, terhadap sesorang atau sekelompok peserta didik yang lain. Oleh karena itu keterampilan guru untuk membaca situasi kelas sangat penting agar yang dilakukan tepat guna. Dengan mengkaji konsep dasar pengelolaan kelas, mempelajari berbagai pendekatan pengelolaan dan mencobanya dalam berbagai situasi kemudian dianalisis, akibatnya secara sistematis diharapkan agar setiap guru akan dapat mengelola proses belajar mengajar lebih baik.

Pembelajaran tematik adalah suatu pendekatan dalam pembelajaran yang secara sengaja mengaitkan beberapa aspek baik dalam intra pelajaran maupun antar mata pelajaran. Pembelajaran tematik meniadakan batas- batas antara berbagai bidang studi dan menyajikan materi pelajaran dalam bentuk keseluruhan. Disamping itu pembelajaran tematik juga mempunyai tujuan agar pembelajaran mampu mewujudkan peserta didik yang memiliki pribadi yang integrated, yakni manusia yang sesuai dan selaras hidupnya dengan sekitarnya. Konsep pembelajaran tematik dapat dipertegas bahwa pembelajaran tematik merupakan pembelajaran yang memadukan antara materi mata pelajaran satu dengan lainnya sehingga meniadakan batas-batas antara berbagai mata pelajaran yang akhirnya akan membentuk 
pengetahuan peserta didik lebih integral. Pembelajaran tematik telah diterapkan di SDN Sudimara 11 Ciledug hal ini terbukti pada kelas V yang telah penulis teliti.

SDN Sudimara 11 Ciledug merupakan pendidikan sekolah dasar yang salah satunya adalah lembaga pendidikan formal di Indonesia. Pendidikan di sekolah dasar tersebut sebenarnya tidak jauh berbeda dengan di sekolah pada umumnya. Berdasarkan hasil observasi dan wawancara yang dilakukan oleh peneliti adalah dengan mewawancarai langsung wali kelas V itu sendiri yaitu Bapak Rusdi Sya'bani, S.Pd. Beliau dapat menguasai kelas dan melaksanakan pembelajaran yang menumbuhkan kebiasaan positif siswa, pembelajaran pun dilaksanakan sesuai dengan alokasi waktu yang tercantum dalam RPP. Akan tetapi pembelajaran hanya terpaku pada buku siswa dan tanpa menggunakan media pembelajaran yang dapat memudahkan guru dalam mentransfer ilmu. Guru hanya menggambarkan benda-benda yang bisa dicontohkan dalam pembelajaran tematik berupa gambar dipapan tulis. Guru juga menjelaskan cara memecahkan masalah dengan penjelasan di papan tulis. Pada akhir pembelajaran, guru tidak meminta siswa untuk membuat rangkuman dari pembelajaran yang dilaksanakan pada hari itu. Beberapa pertanyaan diutarakan guru untuk mengetahui respon siswa terhadap materi yang disampaikannya. Selanjutnya tidak lupa guru memberikan tugas pada siswa untuk dikerjakan di rumah yang dapat melatih siswa.

Dikarenakan pandemi Covid-19 yang sedang melanda Indonesia sehingga pembelajaran dilakukan secara daring. Tugas yang diberikan kepada guru berupa foto hasil kerja siswa yang dikirimkan melalui whatsapp. Kendala yang terjadi disini yaitu guru tidak dapat memantau siswa secara langsung ketika sedang melakukan proses Kegiatan Belajar Mengajar (KBM) karena pembelajaran dilakukan tanpa bertatap muka. Pemahaman siswa pun tidak dapat dipastikan apakah siswa benar-benar memahami materi yang dipelajari atau tidak. Guru tidak melakukan apersepsi pada awal pembelajaran dan tidak mengaitkan dengan pengetahuan lain. Karena penjelasan materi hanya lewat video yang dikirim lewat whatsapp, padahal akan lebih mudah dipahami jika dalam video tersebut penyampaian materi tersusun rapih sesuai dengan model pembelajaran yang direncanakan sebelumnya. Pembelajaran tematik ini seharusnya membutuhkan penjelasan guru. Media yang digunakan tidak sesuai dengan yang tercantum dalam RPP. Pada RPP tertulis bahwa media pembelajaran menggunakan Gambar, benda nyata yang dapat dibagi-bagi. Akan tetapi, guru hanya 
menggunakan papan tulis sebagai alat untuk menggambarkan materi dalam pembelajaran tematik. Dilihat dari hasil belajar siswa pada pembelajaran pertama masih kurang maksimal.

Menurut (SYAH, 2018) Pengertian Keterampilan ialah kegiatan yang berhubungan dengan urat-urat syaraf dan otot-otot (neuromuscular) yang lazimnya tampak dalam kegiatan jasmaniah seperti menulis, mengetik, olah raga, dan sebagainya. Meskipun sifatnya motorik, namun keterampilan itu memerlukan koordinasi gerak yang teliti dan kesadaran yang tinggi. Dengan demikian, siswa yang melakukan gerakan motorik dengan koordinasi dan kesadaran yang rendah dapat dianggap kurang atau tidak terampil.

\section{Menurut (Sanjaya, STRATEGI PEMBELAJARAN BERORIENTASI STANDAR} PROSES PENDIDIKAN, 2018) Keterampilan dasar mengajar bagi guru diperlukan agar guru dapat melaksanakan perannya dalam pengelolaan proses pembelajaran, sehingga pembelajaran dapat berjalan dengan secara efektif dan efisien. Disamping itu, keterampilan dasar merupakan syarat mutlak agar guru bisa mengimplementasikan berbagai strategi pembelajaran yang akan dibahas pada bab-bab selanjutnya.

Menurut (Suyono \& Hariyanto, BELAJAR dan PEMBELAJARAN, 2016) Keterampilan dasar yang harus dimiliki oleh seorang mengajar pada hakikatnya terikat dengan tafsiran tentang sejauh mana kemampuan para guru mampu didalam menerapkan berbagai variasi metode mengajar. Sebenarnya hal ini terkait dengan dua pertanyaan dasar. Pertama, apakah sebenarnya tujuan pendidikan dan pembelajaran itu, dan apakah cara yang terbaik untuk mencapai tujuan tersebut? Sehingga, pedagogi pada hakikatnya menggambarkan berbagai cara yang dapat diterapkan guru didalam mengajar. Pedagogi adalah seni atau sains tentang bagaimana cara untuk menjadi seorang guru, dan umumnya mengacu kepada strategi, instruksi atau gaya mengajar seorang guru.

Dalam praktik pembelajaran, saat seorang guru sudah menentukan metode apa yang akan digunakan, maka seorang guru memerlukan pemahaman tentang latarbelakang pengetahuan siswanya, lingkungan pembelajarannya dan tujuan pembelajaran. Setiap anak memiliki kemampuan yang berbeda di dalam menyerap informasi dan berbeda dalam cara menunjukkan kemampuannya dalam memahami pengetahuan. Dalam kaitan ini guru berusaha menggunakan berbagai macam gaya dan cara mengajar untuk membantu para siswa menyerap informasi dan memperkuat pemahamannya. Berbagai strategi dan metode digunakan untuk menjamin bahwa semua siswa memiliki kesempatan yang sama dalam 
belajar. Dalam kaitan ini biasanya rencana pembelajaran dilaksanakan dengan berbagai cara yang meliputi: mengajukan pertanyaan, menjelaskan, modeling, membangun kerja sama, dan mendemonstrasikan.

Dari beberapa pengertian para ahli diatas dapat disimpulkan bahwa keterampilan mengajar merupakan kompetensi profesional yang cukup komplek, sebagai integrasi dari berbagai kompetensi guru secara utuh dan menyeluruh. Pendapat yang menyatakan bahwa mengajar adalah proses penyampaian atau penerusan pengetahuan, sudah ditinggalkan oleh banyak orang. Kini, mengajar lebih sering dimaknai sebagai perbuatan yang kompleks, yaitu penggunaan secara integratif sejumlah keterampilan untuk menyampaikan pesan. Pengintegrasian keterampilan-keterampilan yang dimaksud dilandasi oleh seperangkat teori dan diarahkan oleh suatu wawasan. Sedangkan aplikasinya secara unik dalam arti secara simultan dipengaruhi oleh semua komponen belajar mengajar. Guru yang profesional adalah guru yang dapat melakukan tugas mengajarnya dengan baik. Dalam mengajar diperlukan keterampilan-keterampilan yang dibutuhkan untuk kelancaran proses belajar mengajar secara efektif dan efisien.

Menurut pendapat (Wijaya, 2017) pengelolaan kelas adalah suatu usaha yang dilakukan oleh penanggung jawab kegiatan belajar mengajar atau yang membantu dengan maksud agar dicapai kondisi optimal dapat terlaksananya kegiatan belajar mengajar seperti yang diharapkan bersama sesuai dengan tujuan yang telah dicita-citakan bersama dalam rancangan pengajaran termasuk dalam kurikulum.

Menurut pendapat (Erwin, 2018) pengelolaan kelas merupakan salah satu masalah yang rumit, dan guru menggunakan pengelolaan kelas sehingga anak didik dapat mencapai tujuan pengajaran secara efektif dan efisien serta memungkinkan mereka dapat belajar dengan baik. Dengan demikian pengelolaan kelas yang efektif adalah syarat bagi pengajaran yang efektif. Tugas utama dan paling sulit bagi guru adalah pengelolaan kelas karena tudak ada satupun pendekatan yang dikatakan paling baik.

Menurut pendapat ini yang dikemukakan oleh (Djamarah \& Zain, 2016) pengelolaan kelas adalah salah satu tugas guru yang tidak pernah ditinggalkan. Guru selalu mengelola kelas ketika dia melaksanakan tugasnya. Pengelolaan kelas dimaksudkan untuk menciptakan lingkungan belajar yang kondusif bagi anak didik sehingga tercapai tujuan pengajaran secara efektif dan efisien. 
Dalam konteks yang demikian itulah kiranya pengelolaan kelas penting untuk diketahui oleh siapa pun juga yang menerjunkan dirinya ke dalam dunia pendidikan. Maka penting untuk itu mengetahui pengertian pengelolaan kelas dalam hal ini. Pengelolaan kelas terdiri dari dua kata, yaitu pengelolaan dan kelas. Pengelolaan itu sendiri akar katanya adalah "kelola", ditambah awal "pe" dan akhiran "an". Istilah lain dari kata pengelolaan adalah "manajemen". Manajemen adalah kata yang aslinya dari bahasa Inggris, yaitu management, yang berarti ketatlaksanaan, tata pimpinan, dan pengelolaan.

Menurut pendapat yang dikemukakan oleh (Nuraeni, 2018) pembelajaran tematik adalah pembelajaran terpadu yang menggunakan tema untuk mengaitkan beberapa mata pelajaran sehingga dapat memberikan pengalaman bermakna kepada peserta didik.

Diungkapkan oleh Trianto bahwa pembelalajaran tematik dapat dimaknai sebagai pembelajaran yang di rancang berdasarkan tema-tema tertentu. Dalam pembahasannya, tema itu ditinjau dari berbagai mata pelajaran PKN, BAHASA INDONESIA, MATEMATIKA, IPA DAN IPS serta SBK. Pembelajaran tematik menyediakan keluasan dan kedalaman implementasi kurikulum, menawarkan kesempatan yang sangat banyak pada siswa untuk memunculkan dinamika dalam pendidikan. Peserta didik dapat membangun konsep, pengetahuan dan wawasan tentang lingkungan secara konstruktif dan produktif menjawab pertanyaan yang dimunculkan sendiri dan memuaskan rasa ingin tahu dengan penghayatan secara alamiah tentang dunia di sekitar mereka.

\section{METODE PENELITIAN}

Dalam penelitian ini menggunakan pendekatan kualitatif dengan jenis metode penelitian deskriprtif kualitatif. Hal ini dilakukan agar peneliti dapat mendeskripsikan secara jelas dan terperinci. Menurut (Mawardi, 2019, hal 23) "Pendekatan penelitian kualitatif sering disebut dengan naturalistic inquiry (inkuiri alamiah)". Pendekatan kualitatif digunakan berdasarkan penelitian yang berada dilapangan tentang memberikan suatu gambaran apa adanya yang terjadi di dalam penelitian.

Menurut Bogdan dan Taylor (1975), menyatakan bahwa Metodologi kualitatif sebagai prosedur penelitian yang menghasilkan data deskriptif berupa kata-kata tertulis atau lisan dari orang-orang dan perilaku yang dapat diamati (Moleong, 2016, h.4). Jadi, penelitian deskriptif adalah penelitian yang mendeskripsikan atau memperoleh informasi untuk dijadikan sebuah data dan menggambarkan kejadian yang diamati oleh peneliti. Penelitian ini dilakukan di 
SDN Sudimara 11 Ciledug, adapun alasannya memilih tempat di SDN Sudimara 11 Ciledug ini, karena guru-guru di SDN Sudimara 11 Ciledug sudah tersertifikasi serta telah menerapkan pembelajaran tematik sehingga memudahkan peneliti dalam melakukan penelitian. Teknik pengumpulan data yang dilakukan oleh peneliti dalam penelitian ini adalah wawancara, observasi, dan dokumentasi.

\section{HASIL DAN PEMBAHASAN}

Observasi Hasil belajar tematik siswa dengan keterampilan guru dalam pengelolaan kelas pada siswa kelas V SDN Sudimara 11 Ciledug yang dilakukan pada bulan September semester ganjil, lalu observasi kedua dilakukan pada awal bulan januari sedangkan penelitian dilakukan pada bulan Agustus di semester ganjil dengan 4 (empat) kali penelitian. Observasi yang dilakukan adalah untuk menganalisis permasalahan pada keteranpilan guru dalam pengelolaan kelas pada pembelajaran tematik di kelas V SDN Sudimara 11 Ciledug.

Guru yang baik akan memaksimalkan pengajarannya agar sampai kepada peserta didik sebaik mungkin. Salah satu faktor yang dapat membawa keberhasilan itu, ialah guru senantiasa mempersiapkan Rencana Pelaksanaan Pembelajaran (RPP) sebelumnya agar pembelajaran lebih terencana dan terstruktur. Di lain pihak ada juga guru yang berpandangan bahwa RPP tidaklah terlalu diperlukan lantaran meskipun tanpa adanya RPP banyak pembelajaran yang berhasil. Sehingga RPP hanyalah sebagai alat bagi supervisor untuk mengecek pekerjaan guru, alasannya karena guru tidak memiliki waktu untuk menyusun RPP. Padahal dengan adanya RPP guru dapat mempersiapkan hal-hal yang akan diperlukan dalam pembelajarannya seperti materi pembelajaran, media pembelajaran, strategi pembelajaran, metode pembelajaran, instrumen penilaian, dll.

Observasi dilaksanakan pada hari Jumat, 7 Januari 2020. Guru mengawali pembelajaran dengan meminta salah satu siswa yang telah ditunjuk sebagai ketua kelas untuk menyiapkan siswa dan memimpin siswa berdoa menurut kepercayaan masing-masing yang dilanjutkan dengan membaca surat-surat pendek untuk mengawali pembelajaran. Selanjutnya siswa diminta untuk membuka buku paket tematik. Siswa diminta untuk mengisi soal-soal. Selanjutnya guru bersama dengan siswa melakukan diskusi mengenai tugas yang telah dikerjakan. 
Dari deskripsi di atas, dapat diketahui bahwa guru tidak menyampaikan tujuan dari pembelajaran yang akan dicapai pada hari itu dan tidak melakukan apersepsi pada awal pembelajaran. Guru menunjukkan penguasaan materi pembelajaran namun kurang menggunakan model pembelajaran yang sesuai dengan apa yang tercantum di RPP. Akan tetapi, dalam pengaplikasiannya kurang maksimal sehingga setelah mengerjakan soal-soal yang diberikan, hasil belajar siswa masih kurang maksimal.

Penelitian pertama yang dilakukan peneliti dilaksanakan pada hari Senin, 26 Juli 2020. Selama pandemi, guru datang ke sekolah untuk mengisi absensi seperti biasanya dan untuk mata pelajaran tematik, guru menjelaskan materi yang dibahas hari ini melalui video yang hanya berdurasi 5-10 menit dan diberikan kepada siswa dengan menggunakan aplikasi whatsapp melalui grup wali murid, disusul dengan pemberian tugas yang ditentukan oleh guru memberikan materi melalui vtugas kepada siswa melalui aplikasi grup whatsapp. Guru memberikan tugas sesuai dengan jadwal pembelajaran yang sudah tersusun.

Pada hari Senin, 26 Juli 2020, pembelajaran yang dibahas pada buku tematik siswa yang dijelaskan melalui video yang dikirim di whatsapp melalui grup wali murid. Penjelasan materi pembelajaran tematik yang singkat dalam video yang berdurasi 5 menit tersebut diawali dengan membaca doa dan menyapa siswa dilanjut dengan penjelasan materi inti. Guru mengingatkan siswa untuk membaca ulang mengenai pembelajaran tematik yang dipelajari. Dilanjutkan dengan mengisi tugas yang ada pada halaman selanjutnya. Guru memberikan waktu untuk paling lambat mengumpulkan tugas sampai dengan pukul 18.00 WIB. Hal ini berarti alokasi yang tercantum dalam RPP dan pada kenyataannya tidak sesuai. Guru tidak banyak menggunakan keseluruhan model pembelajaran yang direncanakan sebelumnya. Kebanyakan guru menggunakan tulisan berupa pesan whatsapp dalam berkomunikasi. Guru juga tidak memberikan instruksi kepada siswanya untuk membuat rangkuman kecil selama belajar dari rumah untuk memudahkan siswa dalam belajar.

Penelitian kedua dilaksanakan pada hari Selasa, 27 Juli 2020. Guru memberikan arahan kepada siswa untuk mempelajari materi pada Buku tematik. Dalam menyampaikan materi pembelajaran tematik seperti biasa guru memberikan penjelasan singkat melalui video yang dikirimkan. Kemudian guru meminta siswa untuk mengisi soal yang terdapat di halaman tersebut. Pada tugas kali ini seharusnya siswa mengerjakannya secara berkelompok dengan 
Indonesian Journal of Elementary Education

Vol. 2, No. 1, Desember 2020

E-ISSN: 2722-6689

http://jurnal.umt.ac.id/index.php/lJOEE

kelompoknya, namun dikarenakan pembelajaran dilakukan dari rumah, siswa mengerjakannya masing-masing dibantu oleh orangtua-nya di rumah. Pengelolaan kelas pada pembelajaran tematik ini tidak di aplikasikan. Guru tidak menggunakan media pembelajaran sama sekali pada pembelajaran kedua.

Penelitian ketiga dilaksanakan pada hari Rabu, 28 Juli 2020. Penelitian masih dilakukan di ruangan guru SDN Sudimara 11 Ciledug. Pembelajaran tidak dilakukan sesuai alokasi waktu yang ditetapkan. Keterampilan guru dalam pengelolaan kelas pada pembelajaran ini pun belum dilaksanakan sebagaimana mestinya, didalam RPP disebutkan bahwa materi tematik disampaikan dengan menggunakan model pembelajaran. Metode pembelajaran yang digunakan hanya ceramah dalam video dan penugasan. Sedangkan unsur lain berupa kinestestik atau gerak tubuh tidak diterapkan pada pembelajaran keempat ini. Pada akhir pembelajaran guru tidak mengarahkan siswa untuk membuat rangkuman berdasarkan pengetahuan yang telah diperolehnya pada hari ini. Sehingga pembelajaran terlihat hanya mengerjakan tugas yang guru minta untuk kerjakan.

Pada pembelajaran tematik yang dilaksanakan pada hari Kamis 29 Juli 2020 dimana pembelajaran dilakukan dengan melakukan pembelajaran jarak jauh. Dari hasil penelitian yang dilakukan peneliti pada pembelajaran tematik dengan melakukan pembelajaran jarak jauh, guru kelas V kurang memperhatikan RPP yang telah dibuat. Guru tidak menyampaikan tujuan pembelajaran dan apersepsi sebagaimana yang tertera di dalam RPP. Setelah membuka pembelajaran, guru menyampaikan materi yang harus dipelajari pada hari itu dan memberikan tugas dari materi tersebut. Menyampaikan tujuan pembelajaran bertujuan agar siswa mengetahui apa yang harus dilakukan untuk mencapai tujuan pembelajaran. Dengan melakukan apersepsi yang tepat, siswa akan termotivasi dan lebih terfokus pada materi yang akan dipelajari. Guru memberikan penjelasan berupa video atau rekaman suara sebagai media pembelajaran yang akan memudahkan siswa agar lebih mudah memahami pembelajaran.

Seperti yang diungkapkan oleh Blakedan Haralsen bahwa media adalah medium yang digunakan untuk membawa/menyampaikan seseuatu pesan, dimana medium ini merupakan jalan atau alat dengan suatu pesan berjalan antara komunikator dan komunikan (Mudlofir \& Rusydiyah, 2017, h.122). Penggunaan media pembelajaran dipandang penting untuk 
membantu pencapaian pembelajaran. Guru hanya menggunakan unsur visual dan auditory pada video yang di tampilkan. Itupun tidak menggunakan media.

Dilihat daru hasil belajar matematika siswa kelas V yang di dapat dari soal-soal yang diberikan setiap harinya yang kurang mencapai angka maksimum atau masih banyaknya siswa yang mendapatkan nilai belum mencapai KKM. Maka dapat dikatakan model yang digunakan tidak sesuai dalam penyampaian materi pembelajaran ini. Pembelajaran yang dilakukan selama peneliti melakukan penelitian lebih terlihat seperti spontanitas yang kurang terencana, karena kebanyakan pembelajaran berpedoman pada buku paket siswa secara kontinyu.

Dari penelitian yang dilakukan, kegiatan pembelajaran yang dilakukan melalui daring atau Pembelajaran Jarak Jauh (PJJ) tidak sesuai dengan skenario pembelajaran yang tertuang dalam skenario pembelajaran yang dibuat guru tepatnya tidak sesuai dengan RPP yang telah dibuat sebelumnya. Dari hal tersebut, terlihat jelas bahwa RPP hanya dijadikan sebagai kelengkapan administrasi guru sebagai guru bersertifikat pendidik. Dimana kelengkapan administrasi kelas selalu dipantau oleh pihak pengawas. Dalam pembelajaran menyimak, guru terlebih dahulu meminta siswa untuk mendengarkan dengan baik tentang materi yang akan diputar lewat video yang dibagikan guru melalui whatsapp. Disini video guru tersebut yang berperan dalam memaparkan materi pembelajaran. Kemudian guru akan memberikan pertanyaan-pertanyaan yang berkaitan dengan materi yang ada dalam video tersebut atau langsung memberikan tugas yang terdapat dibuku paket pegangan siswa. Peneliti tidak dapat mengetahui apakah siswa benar-benar menyimak pembelajaran dengan baik. Karena pembelajaran jarak jauh akan ada kemungkinan orangtua yang mengambil peran untuk memperhatikan tugas anak-anaknya. Proses tanya jawab antara guru dengan siswa hanya dilakukan secara tertulis. Dalam pembelajaran jarak jauh guru kesulitan untuk memberikan diskusi kelas karena pembelajaran tidak dilakukan dengan tatap muka ataupun zoom meeting, dikarenakan tidak seluruh orangtua siswa memiliki waktu untuk mendampingi anaknya belajar karena harus bekerja. Guru memberikan pertanyaan berupa pesan teks whatsapp yang kemudian memberikan instruksi untuk siswa menjawab.

\section{SIMPULAN DAN SARAN}


Berdasarkan hasil penelitian yang dilakukan penulis dapat disimpulkan bahwa keterampilan guru dalam pengelolaan kelas pada pembelajaran tematik kelas V di SDN Sudimara 11 Ciledug belum diaplikasikan dengan baik dan benar sesuai dengan langkahlangkah yang direncanakan sebelumnya pada RPP. Akibatnya masih banyak siswa yang merasa kebingungan mempelajari materi pada pembelajaran tematik. Terlebih proses pembelajaran dilakukan secara tidak langsung atau daring di masa pandemic ini. Tidak hanya itu, beberapa diantara siswa memiliki orang tua yang keduanya sibuk bekarja. Sehingga mereka mengerjakan tugas hanya mengandalkan buku paket dan informasi dari wali murid lain.

Masalah selanjutnya yaitu penggunaan media pembelajaran yang tidak sesuai dengan apa yang tertulis di dalam RPP. Terkadang secara spontan guru menggunakan media yang tidak direncanakan sebelumnya sehingga terkesan mendadak dan kurang terorganisir dengan baik, akibatnya pembelajaran menjadi kurang berkesan dan bermakna. Selain itu, penetapan waktu yang digunakan pun kurang diperhatikam. Waktu yang diberikan oleh guru terlalu banyak sehingga terkadang membuat siswa kurang termotivasi untuk belajar dan mengerjakan tugas yang diberikan.

Berdasarkan hasil kesimpulan, maka peneliti memberikan saran kepada:

1. Pihak sekolah

Kepala sekolah hendaknya sering melakukan kerja sama dengan sekolah sekolah lain serta pihak atau lembaga lain yang terkait untuk mengadakan workshop guna meningkatkan kualitas guru, baik kualitas administrasi maupun kinerjanya. Kegiatan tersebut dilakukan demi meningkatkan kemampuan guru dan majunya kualitas pendidikan, terutama pada penguasaaan berbagai macam model pembelajaran

2. Bagi guru

Guru agar lebih profesional dalam menjalankan tugasnya, baik administrasi maupun dalam pembelajaran. Terutama pada proses pembelajaran, karena guru diharapkan menyampaikan materi dengan baik dan benar sesuai dengan langkah-langkah yang telah di rencanakan sebelumnya. Agar siswa lebih mudah memahami apa yang disampaikan dan nilai yang didapatkanpun mencapai nilai yang diharapkan.

3. Bagi peneliti selanjutnya 
Indonesian Journal of Elementary Education

Vol. 2, No. 1, Desember 2020

E-ISSN: 2722-6689

http://jurnal.umt.ac.id/index.php/IJOEE

Dengan adanya penelitian ini, semoga dapat dijadikan contoh pembelajaran Kedepannya. Agar terus memperbaiki diri dan mampu menguasai apa yang seharusnya dikuasai sebagai seorang guru terutama dibidang administrasi dan proses pembelajaran. Agar menjadi guru yang professional khususnya bagi calon pendidik agar dapat mempersiapkan diri sebelum menjadi contoh bagi murid dan masyarakat.

\section{DAFTAR PUSTAKA}

Djamarah, B. S., \& Zain, A. (2016). Strategi Belajar Mengajar. Jakarta: Katalog Dalam Terbitan .

Erwin, W. (2018, november selas). Pengelolaan Kelas. Cerdas Pengelolaan Kelas, hal. 1.

Mawardi. (2019). Desain Penelitian Tindakan Kelas. Yogyakarta: Katalog Dalam Terbitan (KDT).

Moleong. (2016). METODE PENELITIAN KUALITATIF. Bandung: PT Remaja Rosdakarya Offset.

Nuraeni, Y. (2018). Pembelajaran Tematik. Bogor: Cahaya Pelajar.

Sanjaya, W. (2018). Strategi Pembelajaran Berorientasi Standar Proses Pendidikan. Jakarta: Fajar Interprtama Mandiri.

Suyono, \& Hariyanto. (2016). Belajar dan Pembelajaran. Bandung: PT Remaja Rosdakarya Offset.

Wijaya, C. (2017, Agustus Kamis). Pengelolaan Kelas. Kemampuan Dasar Guru Dalam Proses Belajar Mengajar, hal. 1. 